\title{
BRIEF CONSIDERATIONS ON THE INFLUENCES OF THE UNION'S PROVISIONS IN THE NEW ROMANIAN CIVIL CODE
}

\author{
E.N Vâlcu, I. Didea
}

\section{Elise-Nicoleta Vâlcu}

Faculty of Law and Administrative Sciences

University of Pitesti, Pitesti, Romania

Address: University of Pitesti, Faculty of Law and Administrative Sciences, 71 Republicii

Blvd., Pitesti, Postal Code 110014

Email: elisevalcu@yahoo.com

\section{Ionel Didea}

Faculty of Law and Administrative Sciences

University of Pitesti, Pitesti, Romania

Address: University of Pitesti, Faculty of Law and Administrative Sciences, 71 Republicii

Blvd., Pitesti, Postal Code 110014

Email: prof.didea@yahoo.com

\section{Abstract}

Considering that on 1 October 2011 took place a real reform of the international private law with the entrance into force of the new Romanian Civil Code, the provisions of the international private law were gathered in Book VII "International Private Law Provisions", aiming to integrate the revised Law No 105/1992 to synchronize its provisions with the new conception on family law stated in the code and with the European and international instruments in the area of international private law. Specifically, the provisions of the new Civil Code on contractual and extra-contractual obligations are in accordance with the European law found in Regulation (EC) No 593/2008 of the European Parliament and the Council of 17 June 2008 on the law applicable to contractual obligations (Rome I), as well as in Regulation (EC) No 864/2007 of the European Parliament and of the Council of 11 July 2007 on the law applicable to non-contractual obligations (Rome II).

Keywords: the principle of autonomy of will, objective criteria, habitual residence, characteristic performace, regulation

\section{Introduction}

Law No 71/2001 is the law applying Law No 277/2009 on the Romanian Civil Code, published in the Official Gazette No 409/10 June 2011 and entered into force on 1 October 2011, except for 8 articles expressly stated which entered into force on 13 June 2011 (according to Art 221). In turn, Law No 71/2001 was modified by Government Emergency Injunction No 79/2011 ${ }^{1}$ published in the Official Gazette No 696/30 September 2011. The new Civil Code repealed several important legislative norms, of which we mention the Civil Code of 1865 , Commercial Code of 1887 , as well as Law No 105/1992 on the regulation of the private international law rapports.

\footnotetext{
${ }^{1}$ Also, Government Emergency Injunction No 80/2011published in the Official Gazette No 694/30 September 2011 modifies the Law No 119/1996 on marital status documents, for compatibility with the new Civil Code. In the Official Gazette No 666/19 September 2011 was published the Order from the Minister of Justice No $1786 / 2011$ approving the Methodological Norms on the organization and function of the National Register of the matrimonial regimes, the registering and consultation procedure.
} 


\section{Theoretical aspects on the influence of Union's norms in the new Civil Code regarding the issue of the law applicable to contractual obligations}

Chapter 7 of Book VIII states the "Obligations", specifically the "law applicable to contractual obligations" and the "law applicable to non-contractual obligations".

Art 2640 of the NCC on the "law applicable to contractual obligations"4 states that "the law applicable to contractual obligations is determined according to the EU regulations" is in line with Regulation (EC) No 593/20085.

Specifically, the Regulation (EC) No 593/2008 mentions the issue of the conflict-oflaw rule, stating that the contract is governed by the law chosen by the parties. This choice must be express or to result, with a reasonable degree of certainty, from the circumstances of the cause or from the statement in the contract of the pactum de lege utenda clause. By their choice, the parties may state a law applicable for the entire contract or for just one part.

Art 2640, like the Union's provisions, states the principle of autonomy of will as main rule in determining the law applicable, according to which the parties choose the law applicable for their contract, but equally it offers the possibility to reconsider their initial choice.

According to Art 3 Para 2 of the Regulation the parties may at any time agree to subject the contract to a law other than that which previously governed it, whether as a result of an earlier choice made under this article or of other provisions of this Regulation. Any change in the law to be applied that is made after the conclusion of the contract shall not prejudice its formal validity or adversely affect the rights of third parties. Art 4 states the objective criterion in determining the law applicable to the contract in the absence of a choice. Considering this criterion we mention Art 4 Para 1 which refers to the concept of habitual residence.

The new Civil Code has the merit of assimilating the concept used by the Union, namely "habitual residence" instead of "domicile". In this regard, Art 19 of the Regulation (EC) No 593/2008 the habitual residence of companies and other bodies, corporate or unincorporated, shall be the place of central administration. The habitual residence of a natural person acting in the course of his business activity shall be his principal place of business.

If the applicable law was not chosen by both parties, it shall be determined by the objective criterion of the habitual residence, the Regulation stating in this regard:

a) a contract for the sale of goods shall be governed by the law of the country where the seller has his habitual residence;

b) a contract for the provision of services shall be governed by the law of the country where the service provider has his habitual residence;

c) a contract relating to a right in rem in immovable property or to a tenancy of immovable property shall be governed by the law of the country where the property is situated;

d) notwithstanding point (c), a tenancy of immovable property concluded for temporary private use for a period of no more than six consecutive months shall be governed by the law of the country where the landlord has his habitual residence, provided that the tenant is a natural person and has his habitual residence in the same country;

e) a franchise contract shall be governed by the law of the country where the franchisee has his habitual residence;

\footnotetext{
${ }^{2}$ Art 2640 of the New Romanian Civil Code.

${ }^{3}$ Art 2641 of the New Romanian Civil Code.

${ }^{4}$ Art 2640 of the New Romanian Civil Code.

${ }^{5}$ Regulation (EC) No 593/2008 of the European Parliament and of the Council of 17 June 2008 (Rome I)'.
} 
f) a distribution contract shall be governed by the law of the country where the distributor has his habitual residence;

g) a contract for the sale of goods by auction shall be governed by the law of the country where the auction takes place, if such a place can be determined;

h) a contract concluded within a multilateral system which brings together or facilitates the bringing together or multiple third-party buying and selling interests in financial instruments, as defined by Article 4(1), point (17) of Directive 2004/39/EC, in accordance with non-discretionary rules and governed by a single law, shall be governed by that law.

The Union's Regulation offers a subsidiary solution in Art 4 Para 2 namely, "the habitual residence of the party required to effect the characteristic performance of the contract". The text is not foreign to us to the idea that the Law No 105/1992 referred to the concept of "characteristic performance", a much commented concept by the Romanian legal literature.

Thus, if the contract is not governed by one of the above situations, it shall be governed by the law of the country where the party required to effect the characteristic performance of the contract has his habitual residence.

Moreover, Art 4 Para 3 states that where it is clear from all the circumstances of the case that the contract is manifestly more closely connected with a country, the law of that other country shall apply. If the law applicable is not determined by the above mentioned provisions, the contract shall be governed by the law of the country to which it is more closely connected.

II. The specificity of the provisions inserted in Regulation (EC) No 593/2008 of the European Parliament and of the Council of 17 June on the law applicable to contractual obligations (Rome I)

On 30 November 2000, the Council adopted a common program of measures for implementation of the principle of mutual recognition of decisions in civil and commercial matters $^{6}$ as base of judicial cooperation in civil matters. The program establishes measures to harmonize the regulations if a conflict of laws occurs, as well as measures easing the mutual recognition of court decisions.

Regarding the material area of application, the Regulation shall apply for all contractual obligations in civil and commercial matters, if there is a conflict of laws.

The following shall be excluded from the scope of this Regulation:

a) questions involving the status or legal capacity of natural persons;

b) obligations arising out of family relationships and relationships deemed by the law applicable to such relationships to have comparable effects, including maintenance obligations;

c) obligations arising out of matrimonial property regimes, property regimes of relationships deemed by the law applicable to such relationships to have comparable effects to marriage, and wills and succession;

d) obligations arising under bills of exchange, cheques and promissory notes and other negotiable instruments to the extent that the obligations under such other negotiable instruments arise out of their negotiable character;

e) arbitration agreements and agreements on the choice of court;

f) questions governed by the law of companies and other bodies, corporate or unincorporated, such as the creation, by registration or otherwise, legal capacity, internal organization or winding-up of companies and other bodies, corporate or unincorporated, and

\footnotetext{
${ }^{6}$ OJ C 12, 15.01.2001, p. 1.
} 
the personal liability of officers and members as such for the obligations of the company or body;

g) insurance contracts arising out of operations carried out by organizations other than undertakings referred to in Article 2 of Directive 2002/83/EC of the European Parliament and of the Council of 5 November 2002 concerning life assurance ${ }^{7}$ the object of which is to provide benefits for employed or self-employed persons belonging to an undertaking or group of undertakings, or to a trade or group of trades, in the event of death or survival or of discontinuance or curtailment of activity, or of sickness related to work or accidents at work ${ }^{8}$.

The law applicable to a contract by virtue of this Regulation shall govern in particular:

a) interpretation;

b) performance;

c) within the limits of the powers conferred on the court by its procedural law, the consequences of a total or partial breach of obligations, including the assessment of damages in so far as it is governed by rules of law;

d) the various ways of extinguishing obligations, and prescription and limitation of actions;

e) the consequences of nullity of the contract.

In relation to the manner of performance and the steps to be taken in the event of defective performance, regard shall be had to the law of the country in which performance takes place.

\section{Contracts of carriage}

To the extent that the law applicable to a contract for the carriage of goods has not been chosen by the parties, the law applicable shall be the law of the country of habitual residence of the carrier, provided that the place of receipt or the place of delivery or the habitual residence of the consignor is also situated in that country. If those requirements are not met, the law of the country where the place of delivery as agreed by the parties is situated shall apply.

To the extent that the law applicable to a contract for the carriage of passengers has not been chosen by the parties, the law applicable shall be the law of the country where the passenger has his habitual residence, provided that either the place of departure or the place of destination is situated in that country. If these requirements are not met, the law of the country where the carrier has his habitual residence shall apply.

The parties may choose as the law applicable to a contract for the carriage of passengers only the law of the country where:

a) the passenger has his habitual residence;

b) the carrier has his habitual residence;

c) the carrier has his place of central administration;

d) the place of departure is situated;

e) the place of destination is situated.

2. The present Regulation defines consumer contracts $^{9}$ as being a contract concluded by a natural person for a purpose which can be regarded as being outside his trade or profession (the consumer) with another person acting in the exercise of his trade or profession (the professional) shall be governed by the law of the country where the consumer has his habitual residence, provided that the professional ${ }^{10}$ :

\footnotetext{
${ }^{7}$ OJ L 345, 19.12.2002, p.1 amended by Directive 2008/19/EC (OJ L 76, 19.03.2008, p. 44).

${ }^{8}$ The Regulation does not apply for proofs and procedural aspects in fiscal, customs and administrative areas.

${ }^{9}$ Art. 6 of the Regulation.

${ }^{10}$ The provisions are not applicable for: a) a contract for the supply of services where the services are to be supplied to the consumer exclusively in a country other than that in which he has his habitual residence; b) a
} 
a) pursues his commercial or professional activities in the country where the consumer has his habitual residence;

b) by any means, directs such activities to that country or to several countries including that country.

\section{Voluntary assignment and contractual subrogation ${ }^{11}$}

The concept of assignment in this Regulation includes outright transfers of claims, transfers of claims by way of security and pledges or other security rights over claims.

The relationship between assignor and assignee or subrogated under a voluntary assignment or contractual subrogation of a claim against another person (the debtor) shall be governed by the law that applies to the contract between the assignor and assignee under this Regulation.

The law governing the assigned or subrogated claim shall determine its assignability, the relationship between the assignee and the debtor, the conditions under which the assignment or subrogation can be invoked against the debtor and whether the debtor's obligations have been discharged.

\section{Legal subrogation ${ }^{12}$}

Where a person (the creditor) has a contractual claim against another (the debtor) and a third person has a duty to satisfy the creditor, or has in fact satisfied the creditor in discharge of that duty, the law which governs the third person's duty to satisfy the creditor shall determine whether and to what extent the third person is entitled to exercise against the debtor the rights which the creditor had against the debtor under the law governing their relationship.

\section{Multiple liability ${ }^{13}$}

If a creditor has a claim against several debtors who are liable for the same claim and one of the debtors has already satisfied the claim in whole or in part, the law governing the debtor's obligation towards the creditor also governs the debtor's right to claim recourse from the other debtors. The other debtors may rely on the defenses they had against the creditor to the extent allowed by the law governing their obligations towards the creditor.

\section{6. $\quad$ Set-off ${ }^{4}$}

Where the right to set-off is not agreed by the parties, set-off shall be governed by the law applicable to the claim against which the right to set-off is asserted.

\section{Burden of proof ${ }^{15}$}

The law governing a contractual obligation under this Regulation shall apply to the extent that, in matters of contractual obligations, it contains rules which raise presumptions of law or determine the burden of proof. A contract or an act intended to have legal effect may be proved by any mode of proof recognized by the law of the forum, provided that such mode of proof can be administered by the forum.

contract of carriage other than a contract relating to package travel within the meaning of Council Directive 90/314/EEC of 13 June 1990 on package travel, package holidays and package tours; c) a contract relating to a right in rem in immovable property or a tenancy of immovable property other than a contract relating to the right to use immovable properties on a timeshare basis within the meaning of Directive 94/47/EC; d) rights and obligations which constitute a financial instrument and rights and obligations constituting the terms and conditions governing the issuance or offer to the public and public take-over bids of transferable securities, and the subscription and redemption of units in collective investment undertakings in so far as these activities do not constitute provision of a financial service.

\footnotetext{
${ }^{11}$ Art. 10 of the Regulation.

${ }^{12}$ Art. 15 of the Regulation.

${ }^{13}$ Art. 16 of the Regulation.

${ }^{14}$ Art. 17 of the Regulation.

${ }^{15}$ Art. 18 of the Regulation.
} 


\section{Conclusions}

We consider that probably after the Romania's adhesion to the European Union, the application of the principle of supremacy of the communitarian law was strongly felt in the national law.

It is indisputable the influence of the Union's legislation, the creation, approach and interpretation of the new Civil Code. Moreover, the Union's legislative influences are arisen from the will of the authors of the novelty version of the Code, which often expressly refers to the European law, an example being Art. 2640 commented in the paper.

\section{Bibliography}

Fl. A. Baias, E. Chelaru, R Constantinovici, I Macovei (coord.), The New Civil Code, commented on Articles 1-2664, C.H. Beck Publishing-house, Bucharest, 2012;

Regulation (EC) No 593/2008 of the European Parliament and of the Council of 17 June 2008 on the law applicable to contractual obligations (Rome I);

Regulation (EC) No 864/2007 of the European Parliament and of the Council of 11 July 2007 on the law applicable to non-contractual obligations (Rome II);

Directive 2002/83/EC of the European Parliament and of the Council of 5 November 2002 concerning life assurance, amended by Directive 2008/19/EC concerning life assurance, as regards the implementing powers conferred on the Commission (OJ L 76, 19.03.2008);

Council Directive 90/314/EEC of 13 June 1990 on package travel, package holidays and package tours. 